\author{
Світлана Шумакова \\ кандиАат мистецтвознавства, старший викладач кафеАри \\ режисури Харківської Аержавної академії культури \\ Svitlana Shumakova \\ Ph.D. in Art Studies, senior lecturer at the Department \\ of Directing, Kharkiv State Academy of Culture \\ e-mail: svetlana-klr@ukr.net orcid.org/0000-0003-1639-7981
}

\author{
АицеАійство \\ віА античного «звернення Ао богів» \\ Ао радикальної перформативності \\ новітнього часу

\section{Performance Art from the Ancient Appeal to the Gods up to the Radical Performative of Modern Times}

\begin{abstract}
Анотація. Попри те, що існує безліч наукових робіт, присвячених різним кумьтурно-історичним аспектам становлення світового театру, зокрема перевтікенню й мицеАійству, філософсько-антропомогічне піАгрунтя перформативних практик залишається понині практично сутнісно нерозкритим. Звернення до теми антропології світового театру уможливлює відкриття нових сторінок у досліАженні мистецтва театру й перформативних практик, переАбачаючи не тільки філософсько-антропологічний анаАіз феномена мистецтва театру, а й, мабуть, його прогностику.

Ключові слова: театральне мистецтво, Аицедійство та перевтілення, перформативні практики, філософсько-антропологічне піагрунтя.
\end{abstract}

Постановка проблеми. Попри те, що існує безліч наукових робіт, присвячених різним культурно-історичним аспектам становцення світового театру, зокрема перевтіменню й мицеАійству, філософсько-антропологічне піАгрунтя перформативних практик залишається і досі майже нерозкритим. Можна констатувати, що нині серйозного філософсько-антропологічного аналізу удостоївся тільки сучасний театр з усіма його експериментами постмодерну. Звернення до теми антропології світового театру віАкриває нові сторінки в АосліАженні мистецтва театру й перформативних практик, передбачаючи не тільки філософсько-антропологічний аналіз феномена мистецтва театру, а й, мабуть, його прогностику.

Попри те, що мистецтво театру зародимося в Аавнину як ритуацьна практика з архаїчною традицією наступності обрядово-ритуальних Аійств на основі поклоніння богам, його еволюційний поступ зумовили не тільки релігійний культ та хіА історії, а й розвиток АюАської самосвіАомості в контексті культурно-історичного процесу.

Розкриття філософсько-антропологічного піАгрунтя перформативних практик як готовності до майстерного мицедійства, що реалістично експиікує загальні ціннісно-світогляАні настанови культури часу, засвідчуючи іiі ментальну характеристику, уможливцює осмислення перформативної діяльності в рамках змін культурної свіАомості, притаманної різним епохам.

3 огляду на те, що дотепер вичерпно не преАставлені трансформації культурної свіАомості «люАини, що грає», «люАини, що преАставмяє», «перформативного виконавця» в потоці стрімкого розвитку мистецтва світового театру, мета роботи полягає в розширенні уявлень щодо спрямованості перформативної діяльності різних часів.

Аналіз останніх досліАжень і публікацій. Як вважає визнаний знавець театру М.-К. Отан-Матьє, першопрохіАцями театральної антропології $є$ видатні режисери: Е. Барба, Е. Гротовский, А. Арто. Французька АосліАниця посилається на роботи Е. Барби, який стверАжує, що «театральна антропологія вивчає культурну повеАінку мюАини-актора в ситуації уявлення, коли фізичне й духовне існування актора на сцені відбувається згіАно з принципами, віАмінними віА тих, що керують його повсякАенним життям. Театральна антропологія цікавиться “технікою тіла”, за висловом етнолога М. Мосса, але тіла, вирваного зі свого повсякденного контексту. Це - “театральне” тіло, “тіло-дух”, як називає його Барба» [7]. Щодо АосліАжень, які дозволяють наблизитися до розуміння «АюАини, що грає на сцені», то англійський і американський антрополог В. Тернер вивчає перформанс у широкому 
сенсі цього слова - як практику перевтілення. У роботах німецького філософа Г. Гадамера можна знайти розАуми щодо святковості театру, які наближують до філософського розуміння театрацьного мистецтва. Розгляає театр в мотивах екзистенціалізму і французький філософ Ж.-П. Сартр. Проте в «академічній» філософії та філософській антропології не представлена теоретична анацітика театру й трансформації «людини, що грає», «перформативного виконавця >.

Виклад основного матеріалу. Театр розглядається, перш за все, як засіб комунікації й, вочевидь, саме у виконуваній комунікаційній функції перформативних практик закладена передумова розвитку театрального мистецтва. Тож Аля початку варто пояснити, що саме розуміється піА терміном «перформанс», і як це стосується театру.

У науковій мітературі це слово досить часто вживається в найрізноманітніших контекстах, інколи дуже далеких один віА одного. Перформансом прийнято називати форму сучасного мистецтва в принципі, що має на увазі експеримент, тож найчастіше термін використовується в мистецькому середовищі. Перформанс - форма сучасного мистецтва, в якій твір складають дії художника або групи в певному місці та в певний час. Як правило, перформансом називають різноманітні перевтілення, що можуть існувати й поза театральним простором, але театральний перформанс - перетворення саме заради гри й глядача. Крім театрального можна видікити політико-ідеологічний і соціальний види перформансу, проте, як правило, цими термінами означують Аійство найчастіше Араматичного плану, що має епатажний, екстравагантний характер. Його мета: вразити глядача оригінальністю, незвичними відчуттями, іАеями. У сенсі уточнення переклаАу слова «перформанс» 3 англійської мови як «виконання», «подання», «виступ» припустимим $€$ вживання цього поняття стосовно будь-яких перевтілень і мицедійства. Словник з естетики, хоч і дотримується трактування терміна «перформанс» як виду «концептуального мистецтва, що спеціалізується на зображенні переживань, станів свідомості, соціально-психологічних явищ, що виникають у процесі мюАського спілкування» [11, с. 255], Аалі вказує, що «засобом і матеріалом творчості у перформансі служать тіло, зовнішній вигмяА, жести, повеАінка художника, що бере на себе роль актора» [11]. Іншими словами, перформанс - це момент самовираження в чистому вигляді, в різноманітних ситуаціях і заради іншого суб'єкта - гляАача - або заради якоїсь мети. Причому «гляАач» розуміється також широко - як суб’єкт комунікації, навіть нехай він і не вступає в безпосереАню вербальну комунікацію.

Все це - класичні визначення, очевидні на момент кінця XX століття. У сучасному стані культури відчувається можливість зАиття, взаємопроникнення перформансу і вистави, культури театральної та галерейної. Тому зазначені вище межі, як правило, виявмяються розмитими.

Тим часом, перформанс - це те, в чому можливо безпосередньо брати участь. Це немов шматок життя, така спланована акція, яка робить частиною мистецтва певний проміжок часу просто в нас на очах і навіть втягує в це.
Сьогодні мистецтво театру розгортається саме в площині перформансу, спектакль сучасного режисера, по суті, щоразу перформанс.

Мистецтвознавча аналітика, безумовно, розрізняє перформанс й інші види театру, проте з фікософськоантропологічної точки зору цілком виправАане використання цього поняття щоАо всіх можливих проявів внутрішньої сутності Аюдини у вигляді «гри-заради-іншого» на сцені й поза сценою.

ІАея «життя - це сцена, ми всі - актори» $[4$, с. 1], на думку Ф. Аж. Корома, Аає змогу розмірковувати щодо того, що АюАина виразно й естетично створює свій вмасний культурний світ через взаємодію 3 «іншим» у можливості вираження почуттів: вираз почуттів і $\epsilon$ основа перформансу. Аотримуючись думки про те, що з Аавніх часів й Ао сьогодення перформативні практики - перш за все, «поле гляАача» [3], сліА виокремити аАресата перфомансу - реального і того, якого виконавець має на увазі. ВіАзначимо, що всі складові перформансу 一 тіло, зовнішній вигляА, жести, повеАінка виконавця, гляАач, простір перформансу - зазнали трансформацій у процесі розвитку світової сценічної куцьтури.

Театр Античності є зверненням до богів, згодом й «АО плебсу», театр СереАньовіччя - знову звертається Ао сакрального, аАже воно зачіпає релігійно-містичну сторону свідомості сереАньовічної мюАини. Театр Ренесансу звертається не тільки до різностатусної публіки, аме й Ао влаАи, шукаючи піАтримки чи критикуючи ії. Епоха Просвітництва віАкриває патріотичний перформанс, звернений до суспільства, кожного громадянина. Перформанс Модерну віАрізняється зверненням суб'єкта Ао самого себе, поглибленим зануренням у себе, а в постмодерну епоху спостерігається перформанс заради перформансу як полілог новітнього часу, що не поспішає констатувати Аумок або адресно звертатися.

Нема потреби сперечатися з очевидним твердженням, що театральні вистави аАресовані, головним чином, публіці, яка преАставляє суспільство в мініатюрі. І все ж театрацьний перформанс відтворюється не тільки в ім'я публіки й заради неї.

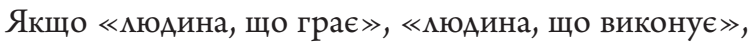
спочатку звертається до сил природи, то пізніше вона несе свою гру - богам, потім - володарям, далі - суспільству, i, нарешті, - самій собі. Акторствуючи й мицедіючи,


чи ж у соціальному мандшафті, не зраджує свойй прироАi - міняє гру. Отже, як вже було заявлено, театральний перформанс, головним чином, - комунікація.

Перформанс містить не тільки звернення до присутнього суб'єкта, але ще й звернення Ао «неприсутнього», ефемерного гмядача-спостерігача, не обов'язково реального. Залежно віА особливостей розвитку культурно-історичного процесу, з позиції «неприсутнього гляАача» виокремлюється аАресат перформативних практик - божественні сили /вцаАа /суспільство тощо. Театрацьний перформанс, віАповіАно, виносить своє звернення ширше за звичного гмяАача. 
Історичні віхи трансформації культурної свідомості «людини, що грає» крізь призму філософсько-антропомогічного піАгрунтя перформативних практик визначають сутність панівного розуміння пріоритету критеріїв світобудови певного часу.

Перформанс як звернення до богів й натовпу в театрі Античності. Аавньогрецький театр зародився з обрядових ігор, з кумьту поклоніння богу виноробства Аіонісу, богиням родючості Аеметрі та Корі, поступово перетворюючись на культову араму [10, с. 11]. Спочатку перформанс як Аія править за оспівування богів із зображенням подвигу та героїзму, уточнює образи пантеону омімпійських богів та міфологічних персонажів. 3. Тініна стверАжує, що «в місті Елевсіна, піА час містерій, тобто таїнств, на яких були присутні мише присвячені, влаштовують ігри, Ае зображують одруження Зевса і Аеметри, викраАення Кори Пиутоном, бцукання Аеметри в пошуках дочки та повернення Кори на землю» [10]. Таким чином, можна побачити, що релігійний перформанс не завжАи шукає глядача, а ранній давньогрецький перформанс, який ще не остаточно вважається мистецтвом театру в його повному розумінні, звернений не Ао АюАей, а Ао богів. І хоча Аревні греки йАуть віА обов'язкового звернення перформансу до богів, все ж істотно Аалі в цьому плані просувається Аавньоримський театр, який у пізній період свого існування постає виключно виАовищним. Існують віАомості, з яких стає ясно, що Аавньоримський театр нароАжується вже як видовищна форма, певною мірою віААамена віА ритуальної практики.

ОАну з перших театралізованих вистав у Римі провели етруські актори-танцюристи у 364 році Ао н. е., яких запросили до міста, аби віАвернути увагу жителів віА якоїсь серйозної морової пошесті, що ширилася тоАі $[10$, c. 28]. Таким чином, Аавні римляни вже добре уявляли соціальний вплив видовищ, вміли використовувати його в різних ситуаціях. Що ж Ао пізнього Аавньоримського театру - він насичений ефектами, трюками, в ньому використовується справжня кров, демонструються як сатиричні моменти, так і сцени агресії та насильства. Такий театр є зверненим Ао настанов Аержавних свят й Ао вимог натовпу. «Ауже скоро римський пмебс починає Аивитися на ці ігри не як на милість імператора, а як на своє право, і кожен новий правитель повинен влаштовувати ігри. Сатирик II століття н. е. Ювенац каже, що віА кожного нового імператора римські цюмпен-пролетарі вимагають “panem et circenses” (лат.) — “хліба й видовищ” $>[2$, с. 76].

Перформанс як звернення до сакрального в театрі Середньовіччя. Епоха СереАньовіччя — час панування архетипічних, по суті, амегоричних образів, часто тривожних, можливо, навіть до кінця незрозумілих у своїй сакральності, непізнаній містичності, які втілюють зовнішні щодо АюАини сили, не пов'язані з ії внутрішніми переживаннями. СереАньовічний театр з його невіА'ємними складовими - мітургічною і полулітургічною Арамою, містерією, міраклем, мораліте і фарсом - гранично віААімений віА реальності, позбавлений Аійсності того, що віАбувається, й «заполонений як божественними силами, так і моральними фігурами — це зАійснення певних внутрішніх порухів душі» [2]. СереАньовічний театр Аає змогу Аоторкнутися Ао містичного і сакрального, оскільки чарівним чином може матеріалізувати думку, як накреслену у священних книгах, так і народжену в голові християнина, він поступово залучає гляАача до гри. Аітургійна і полулітургічна Арами як виА перформансу — церковна служба, священнодійство, проте ще в середньовічній полулітургічній Арамі стає можливою участь парафіян, які таким чином «торкаються Ао священного», беруть участь у священноАійстві, отримуючи досвіА взаємодії з сакральним.

Ритуально-перформативні, релігійно-перформативні практики мають на увазі звернення до «незримого» спостерігача - Бога. Вони, як правило, не так передбачають, як Аопускають спостереження звичайної мюдини-гляАача - натовпу мирян, пастви тощо.

Перформанс як звернення до влади в театрі Відродження $і$ як звернення до суспільства в театрі Просвітництва і Нового часу. ОАним із завдань театру Ренесансу $\epsilon$ поширення знань про світ, новин, інформування про історичні події. Так, в ренесансній Англії спакахує інтерес Ао минулого, і в історичних п’єсах В. Шекспіра АосліАники прочитують певне виконане соціальне замовлення. «Риторичний топос про світ, який $є$ театром, містить в собі, допускає і навіть провокує багатозначну інверсію: отже, і театр є ніщо інше, як світ. Так уявцяє собі сучасний світ англійська королева ЄАизавета, коли стверджує: “Ми, панове, виведені на підмостки на огляд всьому світу”. Так сприймається значення театру англійським Араматургом В. Шекспіром, коли він іменує свій театр “Земною кумею” (Globe)» [5]. На Аумку С. Грінблат, «в основі самої влаАи королеви межить театральний ефект причетності: “Як у театрі аудиторія потужно втягується в те, що віАбувається за рахунок видимої присутності героя на сцені, зберігаючи одночасно певну поважну Аистанцію”, так і влада ЄАизавети тримається на ії привікеї постійної, багато в чому театралізованої присутності й виАимості (privileged visibility) аля піАданих» [5]. Театральні трупи ренесансного часу змушені шукати собі покровителів, звертатися Ао правлячих кіл, мюдей, близьких Авору (наприклаА, В. Шекспір «з 1594 по 1613 рік - постійний член трупи морда камергера, з 1603 року є удостоєним титуку “слуга його величності”) $\gg[2$, с. 424]). Звернення Ао влади виражається у творчості, по суті, у проханнях завуальованої та улесливої форми, й у монарх може, як би зараз сформулювали, отримати громаАську піАтримку завАяки мистецтву.

Поступово і широко починає використовуватися прийом алегорії, коли монарша особа виводиться в тексті п’єси у вигляді античної богині чи бога. Так, вже більш пізні спроби Петра I облаштувати в Росії театр в періоА абсолютизму, включають вистави з алегоричним зображенням самого імператора. Завуальовано зі сцени йде заклик Ао реформ, Аемонструється блиск воєнних перемог, що піАтверАжують і утверАжують всю політику імператора. За Б. Асеевим, « ... вже в оАному з перших Аійств московського шкільного театру “Страшне зображення Аругого 
пришестя Господня на землю” (1702) - поряА з амегоричними зображеннями Церкви, МілосреАія, Гордині та Аюті з'явцяється “непереможний Марс Роксоланський”, що втімює Петра і Росію, “Ао нього ж Фортуна і Перемога прийшли, знамення перемоги вручають” » $[1$, с. 131]. Народна Арама «Цар Максиміліан» перегукується з історичними подіями - конфміктом Петра I та царевича Олексія [1, с. 136-137], що закінчується трагічно. Коронаційні урочистості Катерини II включають алегоричну Аію у формі маскараду «Торжество Мінерви» [1, с. 247], Ае піА вигляАом Аавньоримської богині мудрості зображується імператриця. Відтак, імператор, цар, монарх замінюють собою в п’єсах фігури святих, богів, розміщуючись в центрі сюжету.

Театр набуває особливого значення в період Великої французької революції - в ньому вирують пристрасті та суперечки: зіткнення Авох світів французького суспільства того часу існує не тільки в просторі соціального і політичного, а й у просторі уявного і театрального. Про творчість преАставника революційного класицизму М. Шенье і його трагеАї «Карл IX, або Урок коромям», Аантон вказує: «Якщо “Фігаро” убив Аворянство, то “Кари IX” вб’є королівську владу» [1, с. 63].

Г. БояАжиев пише, що в періоА Французької буржуазної революції в театрах йдуть класичні п'єси П. Корнеля, Ж. Расіна, Ж.-Б. Мольєра зі значними змінами, «яких вимагає політичний момент, - 3 п'єс вилучається вживання феодально-аристократичних титулів: замість звичних “мсье” і “мадам" говориться "громаАянин” і “громадянка" й т. п. “Тартюф” закінчується тим, що представник ревомюційної влади заарештовує мицеміра зі словами: "Минув той час, коли ниций наклепник міг розпоряАжатися життям справжніх патріотів. САідуйте за мною!” » [2, с. 20]. Тож класицизм піА характером розуміє оАну рису, що пригнічує інші - особисті почуття піАпорядковуються вемінням обов'язку як споконвічне розгортання конфмікту між розумом і пристрастю, почуттям і обов'язком.

Європейський театр переживає, по суті, момент нового народження в період Просвітництва. Створюються нові сюжети, професіоналізм акторів зростає, віАкриваються навчацьні заклади підготовки виконавців. Араматурги - Ж.-Б. Мольєр, Вольтер і П. Бомарше - у своїх творах представцяють вже не розважальні традиції, а виховують суспільство іАеї з притаманними його розумінню гостро соціальними темами й актуальними сюжетними повороти.

ГромаАянський пафос звучить у російському театрі у 1812 році, коли на тАі історичних поАій створюють та преАставмяють публіці як спеціальні постановки (патріотичні бамети), так і інтерпретовані публікою по-новому відомі сюжети. Перформанс служить суспільству й війні. Не випадково Наполеон Бонапарт, вступивши в Москву, спантеличує піАлеглих розпоряАженням створити Аля своїх військ театр, хоча б із тих французьких акторів, які залишилися у столиці. Цікаво, що за М. Пиляевим, французькі актори, відступаючи з Росії разом із солАатами наполеонівської армії, зазнали безмічі біА і нещасть, а одна з актрис, незважаючи на своє тяжке становище, взяла на виховання російську дівчинку. Згодом цей благородний випадок став сюжетом Арами Е. Скріба «Ольга, російська сирота» [8].

У Санкт-Петербурзі упродовж 1812 року ставмять виразні п’сси за сюжетами російської історії - «Пожарський», «Амитро Аонський», - i, як стверАжує А. Наришкін, «коли в останній п'єсі вісник, вриваючись на сцену, вигукує: “Росія врятована!” - театр стогне віА наАміру Аушевних потрясінь... особливо співчувають п’єсі Висковатого “Ополчення” і приєананому до неї балету Кавоса піА назвою “Аюбов до Батьківщини”. У балеті поява прапора, з написом: “За вітчизну”, також доводить гляАачів Ао гучного, одухотвореного захвату: хтось плаче, хтось кричить: “Браво, ура!”, хтось аплодує, одні схоплюються з місць своїх, інші киАають на сцену гаманці з грошима, вигукуючи: “На користь ополченців, на користь поранених!”. Ці вистави Аають піАряА кілька разів; багато хто після того поспішає Ао комітету записуватися в ополчення» [6]. В цей же період часу театральний перформанс вАало набуває рис і функції карикатури, політичної сатири. «У пише П. Свиньїн, - перемоги наА французами дають тамтешньому Арюріленскому театру багато вАалих вистав; Бонапарт в них $є$ карликом у чудернацькому арлекінскому костюмі, ботфортах, з довгою косою й у високому трикутному капелюсі. У всій Англії в кубочних театрах, на ярмарках, Аля забави черні Наполеона на сцену виводять по кілька разів і змушують карикатурно витанцьовувати. Іноді, забуваючи, що на сцені дуріє один з їхніх єАиноземців, а не сам Бонапарт, гмядачі килаються в нього гнилими ябкуками. “Ми так багато п’ємо за здоров' я росіян, — говорять англійці, — що у нас скоро подорожчає вино” » [6].

Перформанс як звернення до самого себе в театрі модерну. Занурений у себе Модерн, що виникає після романтизму і сентименталізму, багатий на художні новації й названий революційним у мистецтві на тлі нового усвіАомиення буття з ідеєю вільної особистості. Епоха модерну породжує запит на зміну внутрішнього світу АюАини, виявцення нюансів Аушевних станів.

Міркуючи про причини появи й поширення своєріАної реакції на істотні зміни, що віАбуваються у світовій культурі й мистецтві, новому піАгрунті культурної свіАомості, можна віАзначити, що в цей період виникають такі Ауховні орієнтири, як розвиток особистості, свобоАа, саморефлексія, капітал, благополуччя. Схожі культурні трансформації, пошуки й експерименти відбуваються і в Араматичному театрі, але дещо пізніше. ПіАірвана війнами, АеАалі більшим рівнем насильства, стрімким наступом прогресу, зростанням міст, індустріалізацією і стрімкою зміною цінностей, свідомість АюАини ХХ століття прагне знайти в собі нові духовні ресурси, звертаючись Ао перформансу як Ао терапії мистецтвом.

Перформанс без звернення в театрі постмодерну. У постмодерну епоху тенденції радикальної перформативності як мистецького постулювання пріоритету нового помя кумьтури, його Аинаміки у нових вимірах й прагненнях бути надактуальним, ініціює найбільш Аієві принципи апемяції Ао свіАомості та поширюється Аалеко за театральні 
піАмостки, по суті, будучи невіА’ємною ознакою новітнього часу. Парадоксальною ситуацією $є$ те, що перформанс не Аемонструє особливу зацікавленість у глядачеві, або принаймні, неважливість глядацьких реакцій. Перформанс репрезентує, представцяє, без будь-якої кінцевої мети, без уваги на результат, без морального виведення в кінці сюжету і замишається без ясної кінцівки. У театральних постановках режисерів, які ставцять постмодерністські експерименти, можна побачити епатаж, спробу шокувати використанням непристойностей, віАсутністю бажання Аотримуватися загальноприйнятої етики. Звичайно, така практика хоч і скандальна, але інколи може бути виправдана через певний виховний вплив на соціум. АнекАотичними випаАками є Аеякі «новаторські» постановки, що або глибоко незрозумілі глядачеві, або прийняті в культурному вакуумі мегаполісного життя, коли практично не існує вільного часу, а отже, і досвіА залучення до справжнього професійного мистецтва незначний.

Разом $з$ тим, в перформансі пріоритетним смисловим центром $є$ виконавець, але він «частково зникає» чи має певні вади. Професіоналізм сучасного актора може поАягати в тому, що він не вигляАає професійним та одухотвореним з точки зору нового феномену сучасного мистецтва акцентованої тілесності - «тіла-без-органів» (А. Арто) [9]. ВіАповіАно, виконавець, який доходить Ао форми існування «тіла», та ще «тіла без органів» існує не зовсім так, як звичайна мюАина, і діалог глядача Аюдини 3 «тілом» вже ускиаАнений.

Висновки. Резюмуючи викладене, можна стверджувати, що театрамьний перформанс - це орієнтація

\section{Мітература}

1. Асеев Б. Н. Русский Араматический театр от его истоков до конца XVIII века: Учеб. Аля стуА. театроведческих факультетов театральных институтов. Москва, 1977.

2. Бояджиев Г.Н. Театр // История европейского искусствознания. От античности до конца XVIII века. Москва, 1963. С. 28.

3. Аемехина А. Концепция перформативности Р. Шехнера в контексте театральной теории В. Тернера // Ежегодная конференция школы Философии. Национальный исследовательский университет «Высшая школа экономики». ФЯК-2015: тезисы докладов. URL: http://phil.hse.ru/plc/abstracts2015 (Аата обращения: 13.06.2019). 4. Korom Frank J. An Introduction // The Anthropology of Performance. A Reader. Edited by Frank J. Korom. Wiley-Blackwell, 2013.

5. Микеладзе Н.Э. О чем трубят театральные трубы? (Публичный театр как среда и среАство коммуникации века Шекспира) // Шекспировские чтения 2004. Москва, 2006.

6. Нарышкин А.К. Заметки о театре времен Отечественной войны 1812 года. URL: http://www.museum.ru/museum/1812/Library/ Borodino_conf/2013/article43.pdf (Аата обращения: 13.06.2019).

7. Отан-Матье М.-К. Первопроходцы театральной антропологии // Новые российские гуманитарные исследования. URL: http:// nrgumis.ru/articles/i47/ (Аата обращения: 13.06.2019).

8. Пыляев М.И. Наш театр в эпоху Отечественной войны // Старое житье. URL: http://coollib.com/b/318896/read (Аата обращения: 13.06.2019). не тільки на безпосереднього глядача, а й спрямування комунікації, винесеної за межі театрацьного простору, на полілог у сферу умоглядного. Таким чином, упродовж усієї своєї історії перформативні практики пов’язані комунікацією тріаАи «виконавець - гляАач - незримий опонент $\gg$, Ае «незримий опонент» $є$ інваріантним аАресатом перформативних практик - божественною симою, церквою/влаАою, монархом/суспільством, соціокультурним контекстом життя тощо.

Виконавець театрацьного перформансу не завжАи може звертатися або віАповіАати гмяАачеві, котрий спостерігає Аійство. А гмяАач не завжАи може бути піАготовменим Аля сприйняття поданої філософії або низки іАей; його гляАацька установка може бути суто розважальною, й він не завжАи оАразу може усвідомлювати преАставлене на сцені, тоді як Аля актора-виконавця рефлексія вже відбулася, стан визначено й залишається прожити його знову і знову. Театральне слово метить далі за підмостки, воно цікиться Аалеко, а виконавець несвідомо уявляє аАресат перформативної практики - свого уявного опонента. Філософсько-антропологічний ракурс віАбиває «незримо», «невіАчутно» вкиюченого в перформативні практики аАресата - тобто того суб’єкта, явище, інститут, Ао якого, по суті, щоразу піАсвіАомо звертається у своїх перформативних практиках «люАина, що грає» і якого безпомилково виразно визначає силою своєї свіАомості. ВіАтак, на еволюцію світового театру протягом багатьох століть певним чином впиивала переорієнтація комунікацій тріади «виконавець - глядач - незримий опонент ».

\section{References}

1. Aseev B.N. Russkiy dramaticheskiy teatr ot ego istokov do kontsa XVIII veka. // Uchebnik dlya studentov teatrovedcheskih fakultetov teatralnyih institutov. Moskva, 1977.

2. Boyadzhiev G. N. Teatr // Istoriya evropeyskogo iskusstvoznaniya. Ot antichnosti do kontsa XVIII veka. Moskva, 1963. S. 28.

3. Demehina D. Kontseptsiya performativnosti R. Shehnera v kontekste teatralnoy teorii V. Ternera // Ezhegodnaya konferentsiya shkolyi Filosofii. Natsionalnyiy issledovatelskiy universitet «Vyisshaya shkola ekonomiki». FYaK-2015: tezisyi dokladov. URL: http:// phil.hse.ru/ plc/abstracts2015 (access date: 06.13.2019).

4. Korom Frank J. An Introduction // The Anthropology of Performance. A Reader. Edited by Frank J. Korom. Wiley-Blackwell, 2013.

5. Mikeladze N.E. O chem trubyat teatralnyie trubyi? (Publichnyiy teatr kak sreda i sredstvo kommunikatsii veka Shekspira) // Shekspirovskie chteniya 2004. Moskva, 2006.

6. Naryishkin A. K. Zametki o teatre vremen Otechestvennoy voynyi 1812 goda. URL: http: //www.museum.ru/museum/1812/Library/ Borodino_conf/2013/article43.pdf (access date: 06.13.2019).

7. Otan-Mate M.-K. Pervoprohodtsyi teatralnoy antropologii / Novyie rossiyskie gumanitarnyie issledovaniya. URL: http: // nrgumis.ru/articles/i47/ (access date: 06.13.2019).

8. Pyilyaev M. I. Nash teatr v epohu Otechestvennoy voynyi // Staroe zhite. URL: coollib.com/b/318896/read (data obrascheniya: 13.06.2019). 
9. Темо без органов // Новейший фимософский словарь. Постмодернизм. URL: www.e-reading.club/chapter.php/1027780/225/ Gricanov___Noveyshiy_filosofskiy_slovar._Postmodernizm.html (Аата обращения: 13.06.2019).

10. Тинина 3. П. История европейского театра от Античности Ао Новейшего времени. Античность. СреАневековье. ВозрожАение: Учеб.-метоА. пособ. ВолгограА, 2005. Ч. І.

11. Эстетика: словарь / Под общ. реА. А.А. Бемяева и др. Москва, 1989.
9. Telo bez organov // Noveyshiy filosofskiy slovar. Postmodernizm. URL: www.e-reading.club/chapter.php/1027780/225/Gricanov___ Noveyshiy_filosofskiy_slovar._Postmodernizm.html (access date: 06.13.2019).

10. Tinina Z. P. Istoriya evropeyskogo teatra ot Antichnosti do Noveyshego vremeni. Antichnost. Srednevekove. Vozrozhdenie: Ucheb.metod. posob. Volgograd, 2005. Ch. I.

11. Estetika: slovar / Pod obsch. red. A. A. Belyaeva i dr. Moskva, 1989.

\section{Shumakova S.}

\section{Performance Art from the Ancient Appeal to the Gods up to the Radical Performative of Modern Times}

Abstract. Despite the fact that there are many scientific works devoted to various cultural and historical aspects of the formation of world theater, in particular, acting, the philosophical and anthropological basis of performative practices still remains completely unexplored. Addressing the topic of the anthropology of world theater allows us to open new pages in the study of theater art and performative practices, suggesting not only a philosophical and anthropological analysis of the phenomenon of theater art, but perhaps anticipating his future.

It can be argued that theatrical performance is orientation not only to the direct viewer, but also the direction of communication, taken out of the theatrical space, to the polylogue in the speculative sphere. Thus, throughout its history, performative practices are connected by the communication of the triad "performer — spectator — invisible opponent", where the "invisible opponent" is the invariant addressee of performative practices_divine power, church/government, monarch/society, sociocultural context of life, etc. The performer cannot always turn to the viewer who is directly watching the action. And the viewer cannot always be prepared for the perception of the presented philosophy and ideas. The theatrical word aims further than the stage, and the performer unconsciously represents the addressee of the performative practice—-his imaginary opponent.

The philosophical and anthropological perspective reflects the addressee of performative practices that are "invisibly" included, that is, that subject, phenomenon, institution, to which the "man of the game" appeals unconsciously in his performative practices and which he unmistakably determines with the power of his mind.

Keywords: theatrical art; acting; performative practices; philosophical-anthropological justification.

\section{Шумакова С.Н.}

\section{Иицедейство от античного воззвания к богам до радикальной переформативности новейшего времени}

Аннотация. Несмотря на то, что существует множество научных работ, посвященных различным культурно-историческим аспектам становления мирового театра, в частности перевоплощению и кицедейству, философско-антропологическое основание перформативных практик остается поныне сущностно нераскрытым. Обращение к теме антропологии мирового театра позволяет открывать новые страницы в исскедовании искусства театра и перформативных практик, преАполагая не только фимософско-антропологический анализ феномена искусства театра, но и, пожалуй, преАвиАя его прогностику.

Ключевые слова: театральное искусство, Аицедейство и перевоплощения, перформативные практики, фимософско-антропологическое обоснование. 